"Енергетика і автоматика", №2, 2019 р.

UDC 514.18

\title{
MAPLE-MODELS OF MOTION OF THE PARTICLE ON ROUGH SLOPING DISK GIVEN IN THE POLAR COORDINATION SYSTEM
}

\author{
A. V. Nesvidomin, Candidate of Technical Sciences, Senior Lecturer \\ National University of Life and Environmental Sciences of Ukraine
}

E-mail:a.nesvidomin@gmail.com

\begin{abstract}
To construct agricultural machinery it is important to know the regularities of the motion of a particle (as a material point) on a rough surface of an arbitrary position in a three-dimensional space, which allows us to calculate the structural and kinematic parameters of the working bodies.

The application of computer modeling of the motion of a particle with rough surfaces allows the discarding of bulky analytical transformations in carrying out computational experiments on the analysis of the motion of a particle under different initial conditions of its throw on any rough surface that is in a certain way located in space.

The purpose of the study is the development of Maple-model of motion of a particle on a rough sloping disk.

When studying the motion of a particle on a rough sloping disk, a polar coordinate system was used.

The trajectories of the particle motion on the rough sloping disk have been obtained at various values of the angle of its throw. It is established that under the same initial conditions of the particle throwing, the trajectories of particles on the rough sloping disk are congruent to the trajectories of the particles along a rough sloping plane. At the same time, the position of trajectories relative to the coordinate lines of flat compartments differ considerably.

On the example of the developed model of motion of a particle on a sloping flat disk, it is shown that the trajectories of the particle and its kinematic properties do not depend on the type of parametric determination of the surface.
\end{abstract}

Key words: triedrone, material point, rough sloping disk, trajectory of motion

Topicality. In many technological processes of agricultural production there is a movement of material particles with rough work surfaces of complex shape. Knowledge of the laws of the motion of a particle (as a material point) by a rough surface of an arbitrary position in a three-dimensional space allows us to calculate the structural and kinematic parameters of the working bodies. 
Analysis of recent research and publications. An analytical derivation of the motion of the particle on an inclined plane reduces to the compilation of a system of differential equations of the second order, the dependence of which is the trajectory of the particle, its speed, acceleration, the length of the traversed path, the normal reaction force, the time to its stop, and other trajectory and kinematics characteristics. The sequence of analytic transformations and methods for solving the derivation of a system of differential equations is quite labor-intensive.

Computer simulation of the motion of a particle with rough surfaces allows to discard bulky analytical transformations carried out by a scientist and provide him with a convenient dialogue mode for carrying out the necessary computational experiments on the analysis of the motion of a particle under different initial conditions of its throw on any rough surface that is in a certain way located in space [1].

The purpose of the study is the development of Maple-model of motion of a particle on a rough sloping disk.

Materials and methods of research. A characteristic feature of the developed models of motion of a particle on a plane is its parametric assignment in a rectangular coordinate system. But there are other systems of parametric plane assignment. Thus, in the study of the motion of a particle in a plane that rotates around an axis perpendicular to it, a polar coordinate system for determining the plane compartment is used $[2,3]$. Although the trajectory-kinematic characteristics of the motion of a particle will not depend on the choice of coordinate systems for the determination of the plane, but the form of analytical transformations of the formation of the law of motion of the particle on a sloping plane given in the polar coordinate system will be different. Let's illustrate this on an example of a particle motion study on a rough sloping disk.

Research results and their discussion. Let's write down the parametric equation of an inclined flat disk in the form:

$$
\boldsymbol{R}(u, v)=\boldsymbol{R}\left[v \cos (u) \cos (\xi), v \sin (u)_{s}-v \sin (u) \sin (\xi)\right]
$$


where: $u \in[0 ; 2 \pi], v \in\left[0 ; v_{n}\right]$ - independent curvilinear coordinates of a flat disk; $\xi$ - the angle of rotation of the horizontal flat disk around the axis $O y$ (Fig. 1).

The first quadratic form $d s^{2}$ of flat disk $\boldsymbol{R}(u, v)$ is:

$$
d s^{2}=v^{2} d u^{2}+d v^{2},
$$

where $E_{s} F_{s} G$ - coefficients of the 1 st quadratic form are respectively:

$$
E=v^{2}, F=0, G=1 .
$$

Since the coefficient $F=0$, then the flat disk (1) has orthogonal $u, v$ - coordinate lines.

We substitute expressions $u=u(t), v=v(t) \mathrm{f}$ the desired particle trajectory in the internal $u, v$-coordinates to the equation (3) of the flat disk $\boldsymbol{R}(u, v)$, from which we obtain the trajectory of the particle $r(t)$ in form:

$$
r(t)=r[v(t) \cos (u(t)) \cos (\xi), v(t) \sin (u(t)),-v(t) \sin (u(t)) \sin (\xi)] .
$$

By the equations of the disk $\boldsymbol{R}(u, v)$ and the trajectory $r(t)$ of the particle we define it:

- vector tangent $\tau(t)$ of trajectory $r(t)$ :

$$
\tau(t)=\frac{d}{d t} r(t)=\tau\left[\begin{array}{c}
\cos (\xi)\left(\frac{d}{d t} v(t) \cos (u(t))-v(t) \frac{d}{d t} u(t) \sin (u(t))\right), \\
\frac{d}{d t} v(t) \sin (u(t))+v(t) \frac{d}{d t} u(t) \cos (u(t)), \\
\sin (\xi)\left(v(t) \frac{d}{d t} u(t) \sin (u(t))-\frac{d}{d t} v(t) \cos (u(t))\right)
\end{array}\right],
$$

- the velocity $V(t)$ of the particle:

$$
V(t)=\mid \tau(t) \|=\sqrt{v(t)^{2}\left(\frac{d}{d t} u(t)\right)^{2}+\left(\frac{d}{d t} v(t)\right)^{2}} ;
$$

- the curve $k(t)$ of the trajectory $\boldsymbol{r}(t)$ of the particle: 


$$
k(t)=\frac{2 \frac{d}{d t} u(t)\left(\frac{d}{d t} v(t)\right)^{2}+v(t)\left(\frac{d}{d t} v(t) \frac{d^{2}}{d t^{2}} u(t)-\frac{d}{d t} u(t) \frac{d^{2}}{d t^{2}} v(t)\right)+v(t)^{2}\left(\frac{d}{d t} u(t)\right)^{3}}{\left(v(t) 2\left(\frac{d}{d t} u(t)\right)^{2}+\left(\frac{d}{d t} v(t)\right)^{2}\right)^{3 / 2}} ;
$$

- the vector of normal $\boldsymbol{N}(t)$ to the surface $\boldsymbol{R}(u, v)$ along the trajectory $\boldsymbol{r}(t)$ :

$$
\boldsymbol{N}(t)=\boldsymbol{N}[-v(t) \sin (\xi), 0,-v(t) \cos (\xi)]
$$

- $\quad$ cosines of the angles $\varepsilon$ and $\eta$ between the corresponding vectors $n, N$ and $G$ :

$$
\begin{gathered}
C \varepsilon(t)=\cos (\varepsilon)=\cos \left(\widehat{\left.\boldsymbol{n}_{,} \boldsymbol{N}\right)}=0,\right. \\
\operatorname{C\eta }(t)=\cos (\eta)=\cos \left(\widehat{\left.\boldsymbol{G}_{r} \boldsymbol{N}\right)}=\cos (\xi) .\right.
\end{gathered}
$$

The analytical expressions of the normal vector $n(t)$ of the particle trajectory and its acceleration $\boldsymbol{w}(t)$ are somewhat bulky, and therefore are not given here.

The above expressions allow us to determine the centrifugal force $F_{C}(t)$ and the force of the normal reaction $F_{N}$ of the particle along its trajectory $r(t)$ :

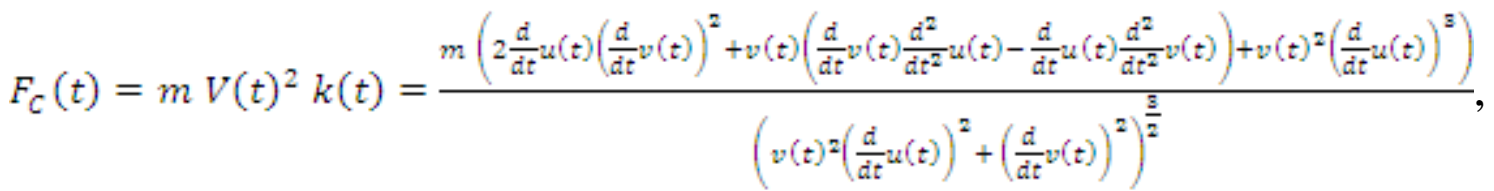

$$
\begin{aligned}
& F_{N}(t)=m g \cos (\varepsilon)+F_{C} \cos (\eta)=m g \cos (\xi) \text {. }
\end{aligned}
$$

To form the law (2.1.30), it is necessary to determine the orts $\boldsymbol{R}_{\mathrm{u}}^{v} \equiv \boldsymbol{u}$ and $\boldsymbol{R}_{v}^{v} \equiv v$ of the local coordinate system $O u v N$, that are tangent to the $u, v$-coordinate lines of the flat $\operatorname{disk} \boldsymbol{R}(u, v)$ :

$$
\begin{gathered}
\boldsymbol{R}_{u}^{\prime}=\frac{d}{d v} \boldsymbol{R}(u, v)=\boldsymbol{R}_{u}^{\prime}[-v(t) \sin (u(t)) \cos (\xi), v(t) \cos (u(t)), v(t) \sin (u(t)) \sin (\xi)], \\
\boldsymbol{R}_{v}^{\prime}=\frac{d}{d v} \boldsymbol{R}(u, v)=\boldsymbol{R}_{v}^{\prime}[\cos (u(t)) \cos (\xi), \sin (u(t)),-\cos (u(t)) \sin (\xi)] ;
\end{gathered}
$$

- $\quad$ the value of the acceleration $W(t)$ :

$$
w(t)=\sqrt{\left(\left(\frac{d^{2}}{d t^{2}} \mathbb{w}(t)\right)^{2}-\mathbb{w}(t)\left(\frac{d}{d t} w(t)\right)^{2}\right)^{2}+4 \frac{d}{d t^{2}} w(t) \frac{d}{d t} w(t)\left(\mathbb{w}(t) \frac{d^{2}}{d t^{2}} w(t)+\frac{d}{d t} w(t) \frac{d}{d t} \mathbb{w}(t)\right)+\left(\mathbb{w}(t) \frac{d^{2}}{d t^{2}} w(t)\right)^{2}} ;
$$

- $\quad$ cosines of the angles between the vector $\boldsymbol{w}(t)$ and the vectors $\boldsymbol{R}_{u}^{r}$ and $\boldsymbol{R}_{v}^{r}$ : 


$$
\begin{aligned}
& C w u(t)=\cos \left(\widehat{\boldsymbol{w}, \widehat{\boldsymbol{R}}_{u}^{\bar{u}}}\right)=\frac{2 \frac{d}{d t} u(t) \frac{d}{d t} v(t)+v(t) \frac{d^{2}}{d t^{2}} u(t)}{W(t)}, \\
& C w v(t)=\cos \left(\widehat{\boldsymbol{W}_{3} \boldsymbol{R}_{v}^{T}}\right)=\frac{\frac{d^{2}}{d t^{2}} v(t)-v(t)\left(\frac{d}{d t} u(t)\right)^{2}}{W(t)} ;
\end{aligned}
$$

- $\quad$ the cosines of the angles between the vector $G[0,0,-1]$ and the vectors $\boldsymbol{R}_{u}^{r}$ and $\boldsymbol{R}_{v}^{r}$ :

$$
\begin{gathered}
\operatorname{CG} u(t)=\cos \left(\widehat{\boldsymbol{G}}, \widehat{\boldsymbol{R}_{u}^{\bar{T}}}\right)=-\sin (u(t)) \sin (\xi), \\
\operatorname{CGv}(t)=\cos \left(\widehat{\boldsymbol{G}}, \widehat{\boldsymbol{R}_{v}^{\bar{T}}}\right)=\cos (u(t)) \sin (\xi) ;
\end{gathered}
$$

- $\quad$ cosines of the angles between vector $\boldsymbol{\tau}(t)$ and vectors $\boldsymbol{R}_{u}$ and $\boldsymbol{R}_{v}^{I}$ :

$$
\begin{aligned}
& C \tau u(t)=\cos \left(\widehat{\boldsymbol{\tau}, \widehat{\boldsymbol{R}_{u}^{\tau}}}\right)=\frac{v(t) \frac{d}{d t} u(t)}{\sqrt{\left.v(t)^{2}\left(\frac{d}{d t} u(t)\right)^{2}+\left(\frac{d}{d t} v(t)\right)^{2}\right)}}, \\
& C \tau v(t)=\cos \left(\widehat{\boldsymbol{\tau}, \boldsymbol{R}_{v}^{\tau}}\right)=\frac{\frac{d}{d t} v(t)}{\sqrt{v(t)^{2}\left(\frac{d}{d t} u(t)\right)^{2}+\left(\frac{d}{d t} v(t)\right)^{2}}} .
\end{aligned}
$$

Then the law of the motion of a particle in projections on the orts $u$ and $v$ of the local coordinate system OuvN on the rough flat disk $\boldsymbol{R}(u, v)$ :

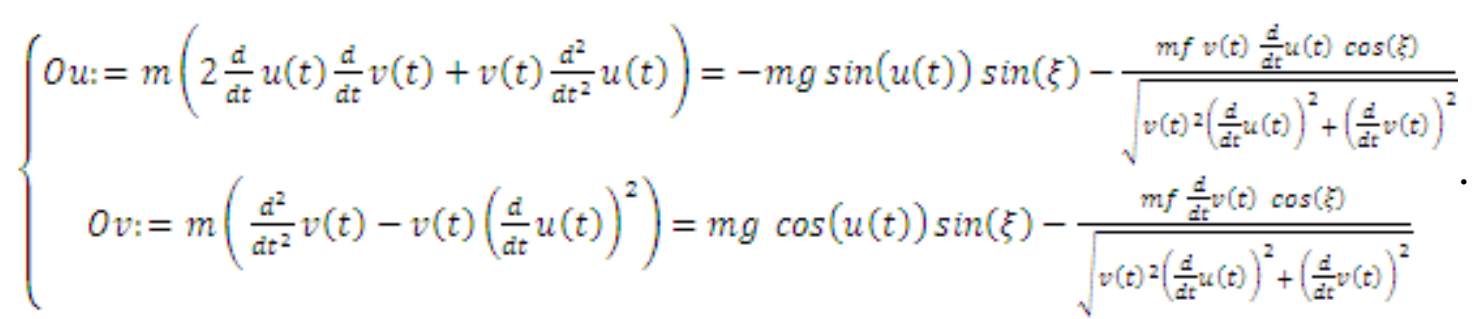

The initial conditions of the solution of the system of differential equations are:

$$
O i=\frac{d}{d t} u(0)=\frac{V_{o} \sin \left(\omega_{0}\right)}{v_{o}}, u\left(t_{0}\right)=u_{o}, \frac{d}{d t} v(0)=V_{o} \cos \left(\alpha_{o}\right), v\left(t_{0}\right)=v_{o},
$$

where: $\alpha_{o}$ - the angle between the vector of the initial velocity $V_{o}$ and axis $O z \equiv v ; V_{o}$ - the initial velocity $V\left(t_{0}\right)$ of the particle in the beginning $t_{0}=0$ of its motion; $u\left(t_{o}\right)=u_{o}, v\left(t_{o}\right)=v_{o}$ - internal $u, v$ - coordinates of the particle position. 
To form the particle motion law in the projections on the orts $\boldsymbol{T}$ and $\boldsymbol{P}$ triendrone of Darboux $\boldsymbol{O T P N}$ we define the vector $\boldsymbol{P}$ as a vector product of the tangent $\boldsymbol{\tau}(\mathrm{t})$ and the normal $N(t)$ :

$$
P(t)=\boldsymbol{\tau}(t) \times N(t)=\boldsymbol{P}\left[\begin{array}{l}
v(t) \cos (\xi)\left(\frac{d}{d t} v(t) \sin (u(t))+v(t) \frac{d}{d t} u(t) \cos (u(t))\right), \\
v(t) \cos (\xi)\left(\frac{d}{d t} v(t) \sin (u(t))+v(t) \frac{d}{d t} u(t) \cos (u(t))\right), \\
v(t) \cos (\xi)\left(\frac{d}{d t} v(t) \sin (u(t))+v(t) \frac{d}{d t} u(t) \cos (u(t))\right)
\end{array}\right] .
$$

The cosines of the angles $\psi, \chi$ and $\varphi$ between the vectors $\boldsymbol{P}_{s} \boldsymbol{n}$ and $\boldsymbol{G}$ are defined:

$$
\begin{aligned}
& C \psi(t)=\cos \left(\widetilde{P_{3} G}\right)=-\frac{\sin (\xi)\left(v(t) \frac{d}{d t} u(t) \sin (u(t))-\frac{d}{d t} v(t) \cos (u(t))\right)}{\sqrt{v(t))^{2}\left(\frac{d}{d t} u(t)\right)^{2}+\left(\frac{d}{d t} v(t)\right)^{2}}}, \\
& C \chi(t)=\cos \left(\widehat{\boldsymbol{P}_{\jmath} n}\right)=-1, \\
& C \varphi(t)=\cos (\widehat{G}, \tau)=-\frac{\sin (\xi)\left(v(t) \frac{d}{d t} u(t) \sin (u(t))-\frac{d}{d t} v(t) \cos (u(t))\right)}{\sqrt{v(t)^{2}\left(\frac{d}{d t} u(t)\right)^{2}+\left(\frac{d}{d t} t(t)\right)^{2}}} .
\end{aligned}
$$

From here we obtain the law of motion of a particle on a sloping rough disk in projections on the orts $\boldsymbol{T}$ and $\boldsymbol{P}$ triendrone of Darboux $\boldsymbol{O T P N}$ :

$$
\left\{\begin{array}{c}
O T=m\left(v(t)^{2} \frac{d}{d t} u(t) \frac{d^{2}}{d t^{2}} u(t)+\frac{d}{d t} v(t)\left(\frac{d^{2}}{d t^{2}} v(t)+v(t)\left(\frac{d}{d t} u(t)\right)^{2}\right)\right)= \\
m g\left(\cos (u(t)) \frac{d}{d t} v(t)-\sin (\xi)(v(t) \sin (u(t))) \frac{d}{d t} u(t)\right)+m f \cos (\xi) \sqrt{\left.v(t)^{2}\left(\frac{d}{d t} u(t)\right)^{2}+\left(\frac{d}{d t} v(t)\right)^{2}\right)} . \\
O P=m\left(\frac{d}{d t} v(t)\left(2 \frac{d}{d t} u(t) \frac{d}{d t} v(t)+v(t) \frac{d^{2}}{d t^{2}} u(t)\right)-v(t) \frac{d}{d t} u(t)\left(\frac{d^{2}}{d t^{2}} v(t)-v(t)\left(\frac{d}{d t} u(t)\right)^{2}\right)\right)= \\
m g \sin (\xi)\left(\frac{d}{d t} v(t) \sin (u(t))+v(t) \frac{d}{d t} u(t) \cos (u(t))\right)
\end{array}\right.
$$

The initial conditions for the solution of the resulting system of differential equations are (22), since in both cases the expressions $u(t)$ and $v(t)$ are sought. It is possible to solve both systems of differential equations only approximately.

In Fig. 1, and the trajectory $r(t)$ of the particle on the rough disk is constructed at different values of the angle of its throw $\alpha_{o}=0^{\circ}, 30^{\circ}, 60^{\circ}{ }_{3} 90^{\circ}$, if the initial velocity of the 
particle is equal to $V_{o}=4 \mathrm{~m} / \mathrm{s}$, the coefficient of friction $f=0.3$, the initial position $u_{o}=\pi, v_{o}=2$ and the angle $\xi=30^{\circ}$ of the inclination of the disk to the plane $0 x y$. None of the particles will stop on the disk, since $f=0.3<\tan \left(\xi=30^{\circ}\right)$. The straight-line trajectory of a particle thrown at an angle $\alpha_{o}=0^{\circ}$ (from the center of the disk to the top) will pass through it - the point $O$. If the initial position of the particle is taken on the horizontal creature disk $-u_{o}=\pi, v_{o}=2$, then under these starting conditions of the trajectory the particles will already be on the other side of the diameter of the disk (Fig. 1, b). Trajectories of particles throw in one direction $\alpha_{o}=120^{\circ}$, but with different initial velocities $V_{o}=2,4,6,8 \mathrm{M} / \mathrm{c}$, is shown in Fig. 1 , c.

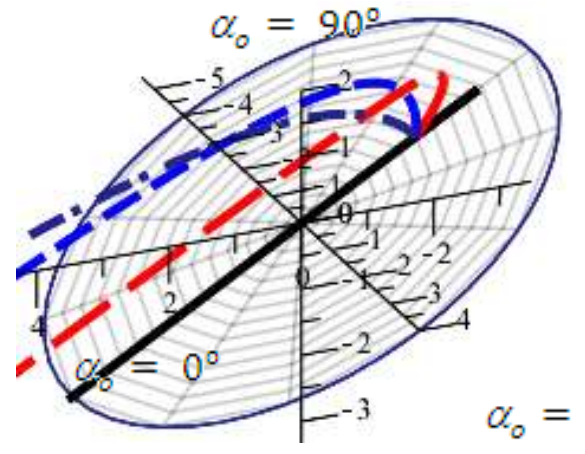

a)

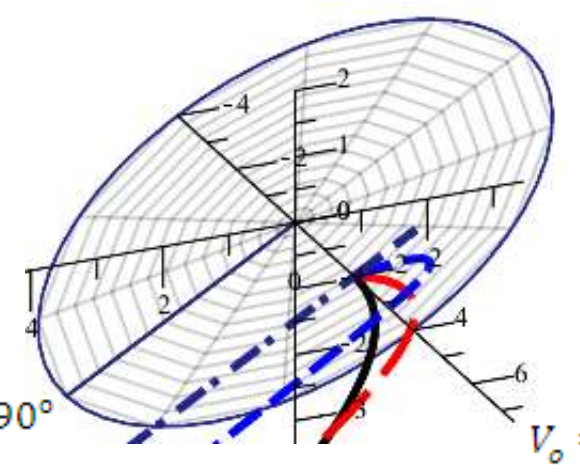

б)

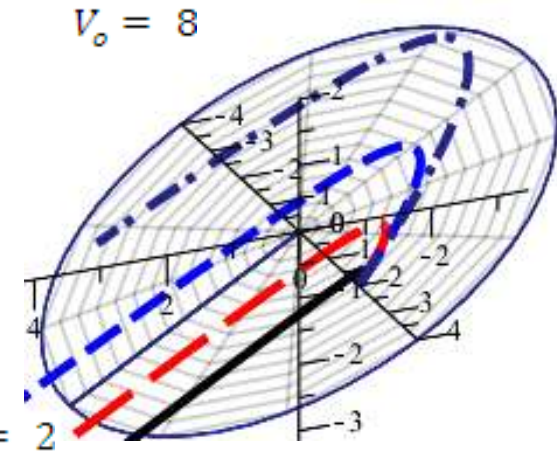

в)

Fig.1 The trajectory $r(t)$ of the particle on the rough disk depending on:

a) the throw angle $\alpha_{o}$ and the initial position $u_{o}=\pi$; b) the throw angle $\alpha_{o}$ and the initial position $u_{o}=1.5 \pi ; \mathrm{c}$ ) the initial velocity $V_{o}$

Let us note that under the same initial conditions, the particles are thrown, and the trajectories of particles on the rough disk (1) are congruent to the trajectories of the particles along a rough sloping plane [4]. At the same time, the position of trajectories relative to the coordinate lines of flat compartments differ considerably. 
Conclusions and perspectives. On the example of the developed model of motion of a particle on a sloping flat disk, the independence of the trajectories of the particle and its kinematic properties from the type of parametric determination of the surface is shown.

\section{List of references}

1. Несвідомін А.В. Моделювання руху частинки по шорсткій горизонтальній площині, яка здійснює прямолінійні коливальні переміщення / А.В. Несвідомін // Сучасні проблеми моделювання: зб. наук праць МДПУ ім. Б. Хмельницького. Мелітополь: МДПУ, 2015. - Вип.4. - С.100-104.

2. Адамчук В.В. Теория центробежных рабочих органов машин для внесения минеральных удобрений: монография / В.В. Адамчук. - К.: Аграрна наука, 2010. $178 \mathrm{c}$.

3. Лінник М.К. Тригранник і формули Френе в задачах кінематики і динаміки частинки у складному русі / М.К. Лінник, Д.Г. Войтюк, С.Ф. Пилипака // Науковий вісник Національного аграрного університету. - 2005. -Вип.80, ч. 1. - С. 271-287.

4. Пилипака С.Ф. Траєкторії руху частинок по шорсткій похилій площині при їх боковій подачі / С.Ф. Пилипака, А.В. Несвідомін // Прикл. геом. та інж. граф. - К.: КНУБА, 2011. - Вип.87. - С.36-41.

\section{References}

1. Nesvidomin, A. V. (2015). Modeliuvannia rukhu chastynky po shorstkii horyzontalnii ploshchyni, yaka zdiisniuie priamoliniini kolyvalni peremishchennia [Modeling of motion of a particle on a rough horizontal plane, which carries out straightline oscillatory displacements]. Suchasni problemy modeliuvannia: zb. nauk prats MDPU im. B. Khmelnytskoho, 4,100-104.

2. Adamchuk, V. V. (2010). Teoriya tsentrobezhnykh rabochikh organov mashin dlya vneseniya mineral'nykh udobreniy: monografiya [Theory of centrifugal working bodies of machines for the application of mineral fertilizers]. Kyiv: Agrarna nauka, 178.

3. Linnyk, M. K., Voitiuk, D. H., Pylypaka, S. F. (2005). Tryhrannyk i formuly Frene v zadachakh kinematyky i dynamiky chastynky u skladnomu rusi [Triangular and Frenne formulas in the problems of kinematics and dynamics of particles in a complex motion]. Naukovyi visnyk Natsionalnoho ahrarnoho universytetu, 80 (1), 271-287.

4. Pylypaka, S.F., Nesvidomin, A. V. (2011). Traiektorii rukhu chastynok po shorstkii pokhylii ploshchyni pry yikh bokovii podachi [Trajectories of motion of particles on a rough slope plane with their side feed]. Prykl. heom. ta inzh. hraf., 87, 36-41. 


\section{МАРЦЕ-МОДЕЛІ РУХУ ЧАСТИНКИ ПО ПОХИЛОМУ ШОРСТКОМУ ДИСКУ, ЗАДАНОГО У ПОЛЯРНІЙ СИСТЕМІ КООРДИНАТ}

А. В. Несвідомін

Анотація. Для конструювання сільськогосподарської техніки важливо знати закономірності руху частинки (як матеріальної точки) шорсткою поверхнею довільного положення в тривимірному просторі, щуо дозволяє провести розрахунок конструктивно-кінематичних параметрів робочих органів.

Застосування комп'ютерного моделювання руху частинки шорсткими поверхнями дозволяє відкинути громіздкі аналітичні перетворення при проведенні обчислювальних експериментів з аналізу руху частинки за різними вихідними умовами ії кидання по будь-якій шорсткій поверхні, яка певним чином розташована в просторі.

Мета дослідження - розробка Maple-моделі руху частинки по шорсткому похилому диску.

При дослідженні руху частинки по шорсткому похилому диску використовувалася полярна система координат.

Отримані траєкторії руху частинки по шорсткому диску за різними значеннями кута ї̈ кидання. Встановлено, щэо за однакових початкових умов кидання частинки побудовані траєкторії частинок на шорсткому диску $\epsilon$ конгруентними до траєкторій частинок по шорсткій похилій площині. У той же час, положення траєкторій відносно координатних ліній плоских відсіків значно відрізняються.

На прикладі розробленої моделі руху частинки по похилому плоскому диску показано, щзо траєкторії частинки та ї̈ кінематичні властивості не залежать від виду параметричного задання поверхні.

Ключові слова: супровідний тригранник, матеріальна точка, похилий шорсткий диск, траскторія руху

\section{МАРЦЕ-МОДЕЛИ ДВИЖЕНИЯ ЧАСТИЦЫ ПО НАКЛОННОМУ ШЕРОХОВАТОМУ ДИСКУ, ЗАДАННОМУ В ПОЛЯРНОЙ СИСТЕМЕ КООРДИНАТ}

\section{А. В. Несвидомин}

Аннотация. Для конструирования сельскохозяйственной техники важно знать закономерности движения частицы (как материальной точки) шероховатой поверхностью произвольного положения в трехмерном пространстве, что позволяет провести расчет конструктивно-кинематических параметров рабочих органов.

Применение компьютерного моделирования движения частицы шероховатыми поверхностями позволяет отбросить громоздкие аналитические преобразования при проведении вычислительных экспериментов по анализу движения частищы с различныли исходными условиями ее бросания по любой шероховатой поверхности, определенным образом расположенной в пространстве. 
"Енергетика і автоматика", №2, 2019 р.

Цель исследования - разработка Марlе-модели движения частиць по шероховатому наклонному диску.

При исследовании движения частиць по шероховатому наклонному диску использовалась полярная система координат.

Получены траектории движения частицы по шероховатому диску с различными значениями угла ее бросания. Установлено, что при одинаковых начальных условиях бросание частицы построенные траектории частии на шероховатой диске являются конгруэнтными $к$ траекторий частии по шероховатой наклонной плоскости. В то же время, положение траекторий относительно координатных линий плоских отсеков значительно отличаются.

На примере разработанной модели движения частицы по наклонному плоскому диску показано, что траектории частиць и ее кинематические свойства не зависят от вида параметрического задания поверхности.

Ключевые слова: сопроводительный трехгранник, материальная точка, наклонный шероховатый диск, траектория движения 